\title{
TO STUDY THE ANALGESIC EFFECT OF INSTILLATION OF 20 ML 0.5\% BUPIVACAINE INTRAPERITONEAL ROUTE AT THE END OF LAPAROSCOPIC SURGERY WITH CONTROL 20 ML 0.9\% SALINE INTRAPERITONEALLY
}

\author{
Rajkumar Reddy Inugala ${ }^{1}$, Murali C. $H^{2}$
}

${ }^{1}$ Assistant Professor, Department of Anaesthesiology, Mahatma Gandhi Hospital/Kakatiya Medical College, Warangal, Telangana. ${ }^{2}$ Assistant Professor, Department of Anaesthesiology, Mahatma Gandhi Hospital/Kakatiya Medical College, Warangal, Telangana.

\begin{abstract}
Laparoscopy involves insufflation of the abdomen by gas, so that the endoscope (usually 6-10 mm in diameter) can view the intra-abdominal contents without being in direct contact with the viscera or tissues. Surgical procedures can be carried out by instruments produced through one or more additional ports. In a systematic review, we evaluated Randomized Controlled Trials (RCTs) of Local Anaesthetics (LA) compared with placebo or no treatment in the control of postoperative pain after laparoscopic surgery. A total of 41 trials with data from 2794 patients were considered appropriate for analysis. Of these 41 RCTs, 13 evaluated intraperitoneal LA after cholecystectomy, four RCTs assessed intraperitoneal LA after other procedures, eight RCTs evaluated portsite infiltration after various procedures, 12 RCTs evaluated mesosalpinx or fallopian tube block after sterilization, and four RCTs considered combined LA regimens.
\end{abstract}

\section{MATERIALS AND METHODS}

This study was conducted in 80 patients aged 30-50 years. The patients were divided into two Groups A - Saline, B - 0.5 Bupivacaine intraperitoneal instillation; 40 patients in each group undergoing elective and emergency surgery.

\section{OBSERVATIONS AND RESULTS}

This study was undertaken to compare the post-operative analgesic effect of $20 \mathrm{~mL} 0.5 \%$ Bupivacaine given intraperitoneally at the end of laparoscopic surgery with control $0.9 \%$ saline $20 \mathrm{~mL}$ at MGM Hospital, C.K.M. Hospital, Kakatiya Medical College, Warangal, during the period from January 2009 to July 2009. Bupivacaine group had better postoperative pain relief in the first six hours with no complications.

\section{CONCLUSION}

$0.5 \%$ Bupivacaine intraperitoneal instillation is effective for abdominal surgeries, especially hysterectomy, appendicectomy and cholecystectomy.

\section{KEYWORDS}

Anaesthesia, Bupivacaine, Intraperitoneal, Saline, Glycopyrrolate, Fentanyl, Lidocaine, Propofol, VAS (Visual Analog Scale).

HOW TO CITE THIS ARTICLE: Inugala RR, Murali CH. To study the analgesic effect of instillation of $20 \mathrm{~mL} 0.5 \%$ bupivacaine intraperitoneal route at the end of laparoscopic surgery with control $20 \mathrm{~mL} \mathrm{0.9 \%}$ saline intraperitoneally. J. Evolution Med. Dent. Sci. 2016;5(68):4885-4890, DOI: 10.14260/jemds/2016/1111

\section{INTRODUCTION}

The modern age of Laparoscopic surgery was ushered with the incorporation of a miniature video camera attached to the eye piece of a laparoscopy allowing many assistants to view the operative field from the same vantage point. Gynaecologic laparoscopic surgery has been routinely performed since 1970. In 1987, Phillipe Mouret described the first laparoscopic cholecystectomy in France.

The technique was introduced in U.S.A. in 1988 by Reddick and Olsen. Improved instrumentation allowed laparoscopic cholecystectomy to revolutionize the upper abdominal surgery in the 1990. Currently laparoscopic gastro-oesophageal, hepatobiliary, colorectal, solid organ (renal/splenic) procedure and herniorrhaphy are routinely performed via minimal access techniques. ${ }^{1}$

Financial or Other, Competing Interest: None.

Submission 14-07-2016, Peer Review 10-08-2016,

Acceptance 16-08-2016, Published 24-08-2016.

Corresponding Author:

Dr. Rajkumar Reddy Inugala,

H. No.: 1-7-1323,

Advocates Colony, Balasamudram,

Hanamkonda, Warangal - Dist.

Telangana State.

E-mail: rajkumaringala@gmail.com

DOI: $10.14260 /$ jemds/2016/1111
Laparoscopy involves insufflations of the abdomen by gas, so that the endoscope (usually $6-10 \mathrm{~mm}$ in diameter) can view the intra-abdominal contents without being in direct contact with the viscera or tissues. Surgical procedures can be carried out by instruments produced through one or more additional ports. Laparoscopy therefore refines the surgical approach and is associated with pain, which is additional to that caused by intra-abdominal trauma. Nevertheless, pain which occurs after this procedure is significantly less and shorter than that caused by the same surgical procedure made possible by laparotomy.

Surgical procedures have been improved to reduce trauma to the patient, morbidity, mortality and hospital stay. With consequent reduction in healthcare costs, the provision of better equipment and facilities along with increased knowledge and understanding of anatomy and pathology has allowed the development of endoscopy for diagnostic and operative procedure. ${ }^{2}$

Starting in 1970 various pathological gynaec conditions were diagnosed and treated using laparoscopy. This endoscopic approach were extended to cholecystectomy in late 1980. 


\section{MATERIALS AND METHODS}

This study was conducted in 80 patients aged $30-50$ years. The patients were divided into two Groups A - Saline, B - 0.5 Bupivacaine intraperitoneal instillation; 40 patients in each group undergoing elective and emergency laparoscopic surgical procedures at M.G.M. Hospital, C.K.M. Hospital, Kakatiya Medical College, Warangal, after seeking ethical clearance from Ethics Committee. An informed consent was taken from all patients after explanation.

All patients were planned for general anaesthesia, induction with propofol and intubation with scoline and maintained with vecuronium.

\section{METHODS}

The present study was conducted in 80 patients aged between 30-50 years. ASA Grade-I and II, undergoing different elective and emergency surgical procedures in Gynaecology, General Surgery, requiring general anaesthesia after taking informed consent.

All the patients were clinically assessed and investigated preoperatively to rule out any systemic disease. Patients undergoing diagnostic laparoscopy, sterilization were excluded. Women with allergies to NSAIDS/Bupivacaine, chronic pain syndrome where pain evaluation was judged unreliable because of neurological diseases or treatment with steroids/NSAIDS/opioids prior to surgery were excluded.

All the cases were assessed pre-operatively for cardiac, respiratory status and fitness for anaesthesia as ASA grading. Routine preoperative consultation and investigations were carried out for all the patients.

The vitals noted during the pre-operative check-up just before getting the patients into the operating room.

Before getting the patient into the operating room, the necessary drugs were loaded and kept ready in labelled syringes.

After establishing IV line, ringer lactate $500 \mathrm{~mL}$ was preloaded. Premedication was given with Glycopyrrolate 15 $\mu \mathrm{g} / \mathrm{kg}$ and fentanyl $1 \mu \mathrm{g} / \mathrm{kg}$. After 3 minutes pre-oxygenation with oxygen anaesthesia was induced by propofol $2 \mathrm{mg} / \mathrm{kg}$ and pre-treating with lidocaine $1.5 \mathrm{mg} / \mathrm{kg}$ body weight. Intubation was done under suxamethonium $2 \mathrm{mg} / \mathrm{kg}$ body weight.

Anaesthesia was maintained with $\mathrm{N} 20+02+$ Sevoflurane $1 \%$ and vecuronium. Monitoring was done with multichannel monitor with NIBP pulse oxygen; ECG continuously till the end of the laparoscopic surgical procedure.

\section{Method of Analgesia}

Incision site of skin was infiltrated with $0.25 \%$ Bupivacaine at the site of trocar introduction under aseptic precautions.

At the end of surgery before removal of trocar, Group B patients were given $20 \mathrm{~mL}$ of $0.5 \%$ of Bupivacaine under vision of video camera into bed of gall bladder, right subdiaphragmatic and open surgical field through trocar. For Gynaecological surgeries over fallopian tubules, appendicular area infiltrated for hysterectomy and appendicectomy respectively.

At the end of surgery patient was given $4 \mathrm{mg}$ ondansetron IV, reversed with standard techniques of recovery with neostigmine $70 \mu \mathrm{g} / \mathrm{kg}$ and glycopyrrolate $15 \mu \mathrm{g}$ for residual neuromuscular blockade.

The patient was shifted to observation room and then to surgical I.C.U. ward after one hour of observations of vital parameters were found to be satisfactory.

In the surgical ward patient was observed for pain with VAS scale from $0,2,4,6,8$ hourly postoperatively. At the same time noting for adverse events like nausea, vomiting, analgesia requirement, shoulder tip pain and total hospital stay in both groups, i.e. Bupivacaine and saline and sent the results for statistical analysis.

\section{OBSERVATIONS AND RESULTS}

80 patients were divided into two groups Group A Saline, Group B $0.5 \%$ Bupivacaine instilled into peritoneal cavity and studied post-operative analgesic effects of both groups were recorded from 0-8 hrs. duration. At the same time side effects like nausea, vomiting, analgesic requirements, shoulder pain, hospital stay were recorded in both groups and tabulated, statistical analysis was done with help of Statistician.

\begin{tabular}{|c|c|c|}
\hline & $\begin{array}{l}\text { Group A } \\
\text { (Saline) }\end{array}$ & $\begin{array}{c}\text { Group B } \\
\text { (Bupivacaine) }\end{array}$ \\
\hline Lap. Hysterectomy & 16 & 15 \\
\hline Lap. Appendicectomy & 15 & 16 \\
\hline Lap. cholecystectomy & 5 & 4 \\
\hline Ovarian Cystectomy & 2 & 1 \\
\hline $\begin{array}{c}\text { SAIO (Sub-Acute } \\
\text { Intestinal Obstruction) }\end{array}$ & 0 & 1 \\
\hline Splenectomy & 0 & 1 \\
\hline Rectoplasty & 1 & 0 \\
\hline Oophorectomy & 1 & 1 \\
\hline Total & 40 & 40 \\
\hline \multicolumn{3}{|c|}{$\begin{array}{c}\text { Table 1: Operative Procedures of the } \\
\text { Patients in Two Groups }\end{array}$} \\
\hline
\end{tabular}

Graph showing VAS scores during laparoscopic postoperative period with $20 \mathrm{~mL} 0.5 \%$ Bupivacaine and 0.9\% $20 \mathrm{~mL}$ of saline instilled intraperitoneally.

\section{Recording of Visual Analog Scale}

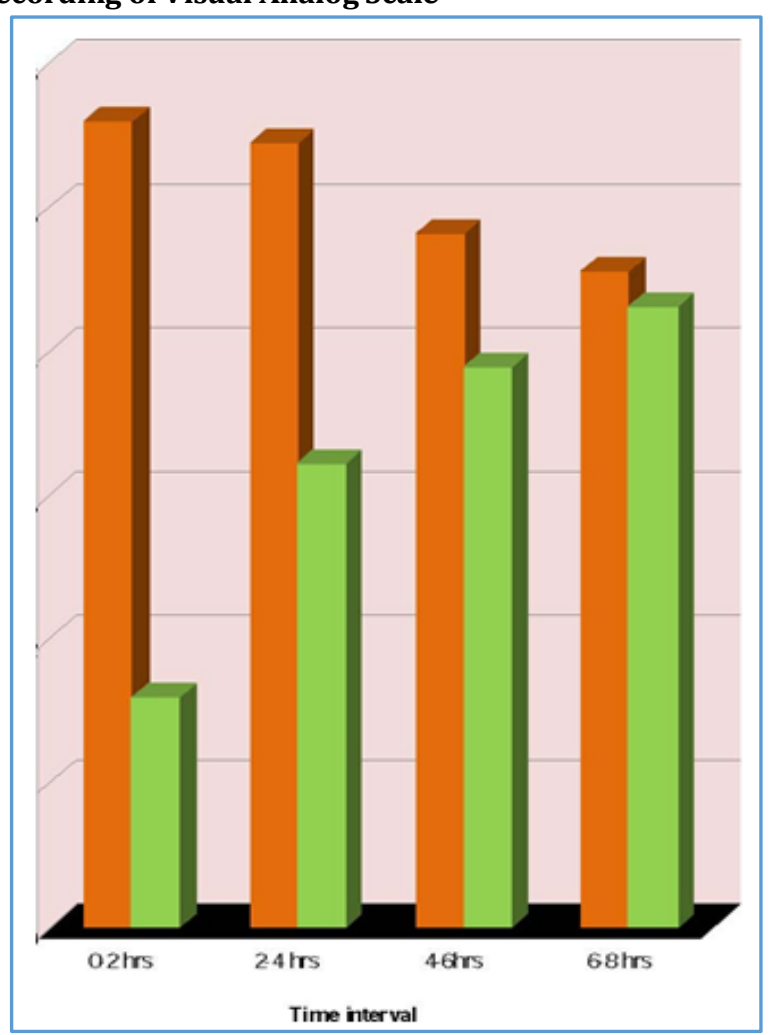


- Group B (0.5\% bupivacaine) shows significantly less VAS score up to $6 \mathrm{hrs}$. of postoperative period.

- After 6 hours both groups were having almost similar score.

\begin{tabular}{|c|c|c|c|}
\hline & $\begin{array}{c}\text { Age } \\
\text { (Years) }\end{array}$ & $\begin{array}{c}\text { Weight } \\
\text { (kg) }\end{array}$ & $\begin{array}{c}\text { P. } \\
\text { Value }\end{array}$ \\
\hline Group A Saline 0.9\% & $38.35 \pm 7.48$ & $50.40 \pm 5.61$ & N.S. \\
\hline $\begin{array}{c}\text { Group B Bupivacaine } \\
0.5 \%\end{array}$ & $39.23 \pm 6.51$ & $53.23 \pm 6.76$ & N.S. \\
\hline \multicolumn{2}{|c|}{ Table 2: Age and Weight Group } \\
\hline
\end{tabular}

Data expressed as Mean \pm SD P value nil significant for both groups for age and weight.

\begin{tabular}{|c|c|c|c|c|}
\hline & 0-2 hrs. & $\mathbf{3 - 4}$ hrs. & 4-6 hrs. & $\mathbf{6 - 8}$ hrs. \\
\hline $\begin{array}{c}\text { Group A } \\
\text { Saline 0.9\% }\end{array}$ & $5.60 \pm 0.59$ & $5.45 \pm 0.55$ & $4.82 \pm 0.44$ & $4.57 \pm 0.50$ \\
\hline $\begin{array}{c}\text { Group B } \\
\text { Bupivacaine } \\
0.5 \%\end{array}$ & $1.60 \pm 1.28$ & $\begin{array}{c}3.22 \pm 3.23 \\
0.53\end{array}$ & $3.90 \pm 0.37$ & $4.32 \pm 032$ \\
\hline \multicolumn{5}{|c|}{ Table 3: Mean VAS of Post-Operative Analgesia } \\
\hline
\end{tabular}

Data expressed as Mean \pm SD

- In Group B (Bupivacaine) early post-operative period, i.e. first 6 hours postoperative pain is significantly less, i.e. mean $(1.6 \pm 1.28)$ than saline Group (A) with VAS score $(5.6 \pm 0.59)$.

At the end of 6 hours of post-operative period both VAS scores are coming close to each other, i.e. mean $4.57 \pm 0.5$ in Group A than mean $4.32 \pm 0.32$ in Group B.

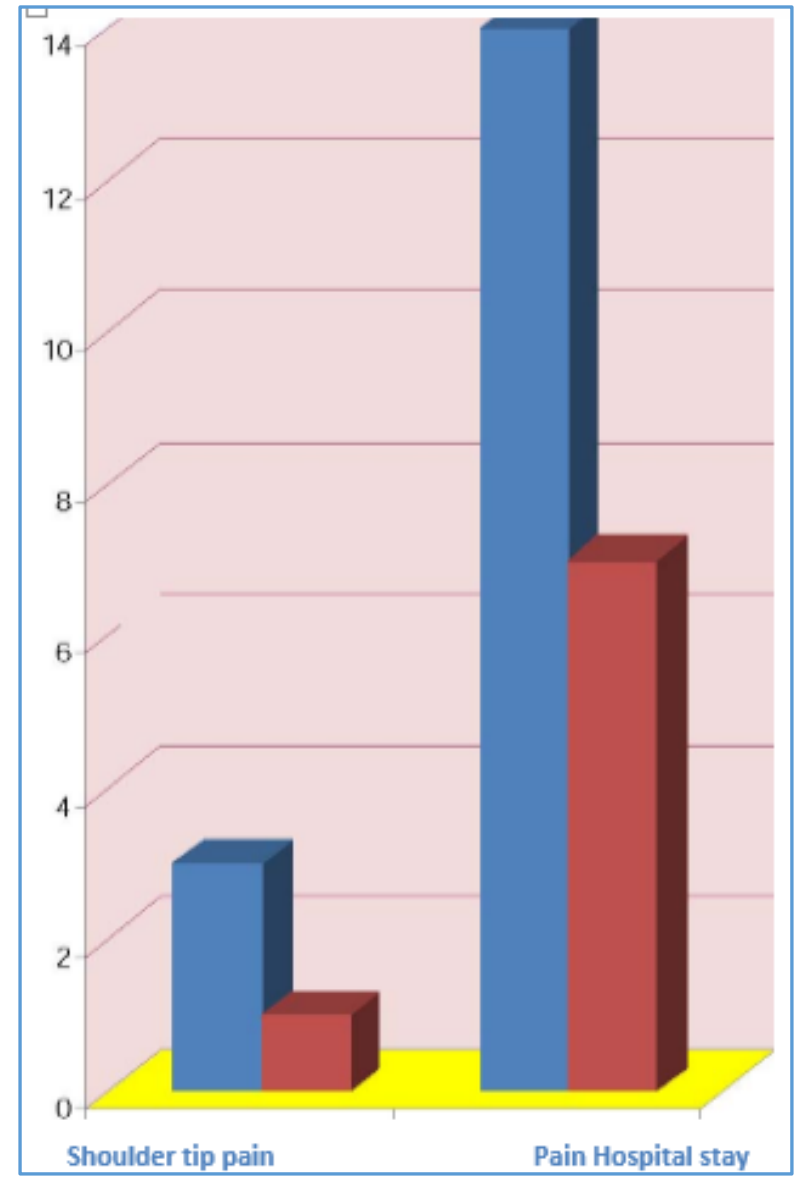

Group A (Saline).

Group B (Bupivacaine).
- Patients given bupivacaine intraperitoneally shows significantly less shoulder pain and hospital stay in comparison with saline group.

Graph showing Early Side Effects during Laparoscopic Post-Operative Surgery for Patients given Bupivacaine Saline Intraperitoneally

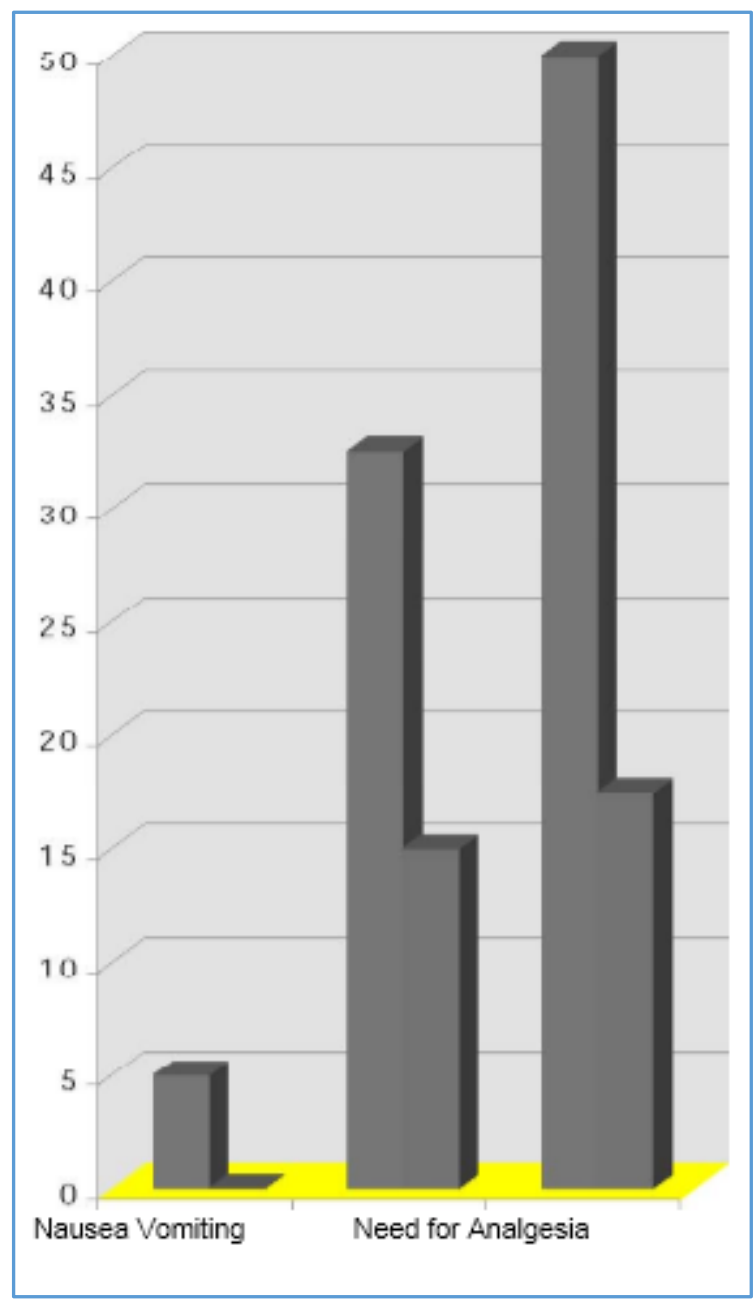

Group A (Saline).

Group B (Bupivacaine).

- Patients given bupivacaine (Group B) intraperitoneally shows significantly less vomiting, nausea and need for analgesics in comparison with saline (Group A).

\begin{tabular}{|c|c|c|c|c|}
\hline & $\begin{array}{c}\text { Group } \\
\text { A } \\
\text { Saline }\end{array}$ & $\begin{array}{c}\text { Group B } \\
\text { Bupivacaine }\end{array}$ & $\begin{array}{c}\text { Chi- } \\
\text { Square } \\
\text { Value }\end{array}$ & $\begin{array}{c}\text { P } \\
\text { Value }\end{array}$ \\
\hline Nausea & $\begin{array}{c}13 \\
(32.5)\end{array}$ & $\begin{array}{c}6 \\
(15 \%)\end{array}$ & 19.32 & $\begin{array}{c}\mathrm{P}< \\
0.0001\end{array}$ \\
\hline Vomiting & $\begin{array}{c}2 \\
(5 \%)\end{array}$ & - & 18.44 & $\begin{array}{c}\mathrm{P}< \\
0.01\end{array}$ \\
\hline $\begin{array}{c}\text { Need for } \\
\text { Analgesia }\end{array}$ & $\begin{array}{c}20 \\
(50 \%)\end{array}$ & $\begin{array}{c}7 \\
(17.9 \%)\end{array}$ & 25.32 & $\begin{array}{c}\mathrm{P}< \\
0.0001\end{array}$ \\
\hline \multicolumn{4}{|c|}{ Table 4: Early Post-Operative Side Effects } \\
\hline
\end{tabular}

- The incidence of nausea was significantly higher in Group A (Saline) 32.5\% compared to Group B Bupivacaine (15\%).

- Vomiting incidence was seen in Group A saline (5\%), but was nil in Group B. 
- Analgesia requirement was significantly higher $(\mathrm{P}<0.0001)$ in Group A, 50\% compared to Group B Bupivacaine (17.5\%).

\begin{tabular}{|c|c|c|c|c|}
\hline & $\begin{array}{c}\text { Group } \\
\text { A } \\
\text { Saline }\end{array}$ & $\begin{array}{c}\text { Group } \\
\text { B } \\
\text { Bupivacaine }\end{array}$ & $\begin{array}{c}\text { Chi- } \\
\text { Square } \\
\text { Value }\end{array}$ & $\begin{array}{c}\text { P } \\
\text { Value }\end{array}$ \\
\hline $\begin{array}{c}\text { Hospital } \\
\text { Stay }\end{array}$ & $\begin{array}{c}14 \\
(3.5 \%)\end{array}$ & $\begin{array}{c}7 \\
(17.9 \%)\end{array}$ & 17.83 & $\begin{array}{c}\mathrm{P}< \\
0.0001\end{array}$ \\
\hline $\begin{array}{c}\text { Shoulder } \\
\text { Tip Pain }\end{array}$ & $\begin{array}{c}3 \\
(7.5 \%)\end{array}$ & $\begin{array}{c}1 \\
(2.5 \%)\end{array}$ & 23.25 & $\mathrm{P}<0.01$ \\
\hline \multicolumn{4}{|c|}{ Table 5: Late Post-Operative Complications } \\
\hline
\end{tabular}

- The number of patients in Hospital stay were $35 \%$ in Group A, which was significantly higher compared to Group B 17\%.

- Pain in shoulder tip was found to be $7.5 \%$ in Group A and $2.5 \%$ in Group B, it is significantly less Group B patients.

\begin{tabular}{|c|c|c|c|c|c|}
\hline & & $\begin{array}{c}\text { 0 to 30 } \\
\text { mins. } \\
\text { Mean }\end{array}$ & $\begin{array}{c}\text { 30 mins. } \\
\text { to } 2 \text { hrs. } \\
\text { Mean }\end{array}$ & $\begin{array}{c}\mathbf{2} \text { to 4 } \\
\text { hrs. } \\
\text { Mean }\end{array}$ & $\begin{array}{c}\mathbf{4} \text { to 8 } \\
\text { hrs. } \\
\text { Mean }\end{array}$ \\
\hline $\begin{array}{c}\text { Group A } \\
\text { Saline } \\
\text { 0.9\% }\end{array}$ & Mean & 89.225 & 89.3 & 87.8 & 84.65 \\
\cline { 2 - 6 } & S.D. & 5.31 & 4.60 & 4.76 & 1.16 \\
\hline $\begin{array}{c}\text { Group B } \\
\text { Bupivacaine } \\
\text { 0.5\% }\end{array}$ & Mean & 79.4 & 84.92 & 87.72 & 87.5 \\
\cline { 2 - 6 } & S.D. & 3.96 & 4.61 & 4.62 & 4.13 \\
\hline
\end{tabular}

Table 6: Post-Operative Haemodynamic Vitals during 0-8 hrs. Pulse Rate Monitoring

During postoperative period of 8 hours, haemodynamics like pulse rate are stable.

\begin{tabular}{|c|c|c|c|c|c|}
\hline & & $\begin{array}{c}\text { 0 to 30 } \\
\text { mins. } \\
\text { Mean }\end{array}$ & $\begin{array}{c}\text { 30 mins. } \\
\text { to 2 hrs. } \\
\text { Mean }\end{array}$ & $\begin{array}{c}\text { 2 to 4 } \\
\text { hrs. } \\
\text { Mean }\end{array}$ & $\begin{array}{c}\text { 4 to 8 } \\
\text { hrs. } \\
\text { Mean }\end{array}$ \\
\hline $\begin{array}{c}\text { Group A } \\
\text { Saline } \\
0.9 \%\end{array}$ & Mean & 92.2 & 92.07 & 92.1 & 90.95 \\
\cline { 2 - 6 } & S.D. & 3.44 & 2.97 & 3.00 & 3.73 \\
\hline $\begin{array}{c}\text { Group B } \\
\text { Bupivacaine } \\
\text { 0.5\% }\end{array}$ & Mean & 86.62 & 87.32 & 87.87 & 88.67 \\
\cline { 2 - 6 } & S.D & 3.85 & 3.70 & 3.71 & 3.28 \\
\hline
\end{tabular}

Table 7: Post-Operative Vital Parameters during 0-2 hrs. Map Monitoring

During postoperative period of 8 hours, haemodynamics like mean arterial pressure are stable.

\section{DISCUSSION}

This study was conducted with intraperitoneal instillation of $20 \mathrm{~mL}$ of $0.5 \%$ Bupivacaine Vs. $20 \mathrm{~mL}$ of $0.9 \%$ saline over 80 patients to study post-operative analgesia.

Post-operative pain is the main factor delaying discharge of patients undergoing day care procedure including laparoscopy and hence adding to hospital cost.

When searching for an optimum regime of pain relief in post-operative period, many analgesics have been investigated for the day case surgery depending on the route of administration. Local Anaesthetics can have an analgesic effect lasting few hours. They have minimal sedative effects that can expedite the discharge of the patient.

Local agents can have an opioid sparing effect. They reduce the nausea and vomiting commonly encountered during general anaesthesia. In this way, they may be able to reach the criteria for early discharge from hospital.

The use of local anaesthetic directly instilled over surgical site, i.e. gall bladder bed and right sub-diaphragmatic space for shoulder pain after cholecystectomy has been shown to reduce pain postoperatively.

The study of Andrei Goldstein ${ }^{3}$ et al for preventing postoperative pain by local anaesthetic instillation after laparoscopic gynaecologic surgery placebo with Bupivacaine and Ropivacaine, he used $20 \mathrm{~mL}$ of $0.5 \%$ Bupivacaine and $0.75 \%$ Ropivacaine at the end of surgery and concluded that both local anaesthetics were effective in prevention of postoperative nausea, vomiting and analgesic requirement was less due to less postoperative pain and shortens the stay in postoperative care unit and decrease nursing care in the ward. This adds to present study.

The study of T. Chundrigar et $\mathrm{al}^{4}$ used $20 \mathrm{~mL} 0.25 \%$ Bupivacaine and $20 \mathrm{~mL}$ of saline for intraperitoneal instillation for postoperative laparoscopic surgery. They concluded bupivacaine group had less pain in the early postoperative period and lower incidence of pain right hypochondrium. Intraperitoneal bupivacaine is simple and effective for treatment of postoperative pain after laparoscopic surgery.

Another study of Narchi P, Benhamou D and Fernandez $\mathrm{H}, 5$ during 1991 (Lancet) done intraperitoneal bupivacaine and $0.5 \%$ lignocaine and $80 \mathrm{~mL}$ saline. He assessed pain by VAS and concluded both (analgesics) local anaesthetics were effective in reducing postoperative shoulder pain than control or saline. Analgesic requirement were greater in nontreatment group than in local anaesthetic group. Intraperitoneal local anaesthetic administration during laparoscopy is both a non-invasive and an efficient method of reducing the intensity of post-operative pain. Present study correlates with above study.

Maharjan SK, Shrestha S. ${ }^{6}$ conducted intraperitoneal and periportal injection of bupivacaine for pain of laparoscopic cholecystectomy of bupivacaine and $0.9 \%$ saline in control. The procedure of intraperitoneal bupivacaine injection is effective in decreasing the pain after laparoscopy cholecystectomy. Present study also correlates with the above study.

The study of S. Berven et al ${ }^{7}$ concludes $0.5 \%$ Bupivacaine 30 cc intraperitoneally diminish postoperative pain, especially shoulder pain, abdominal pain and decrease hospital stay. Long acting local anaesthetics provide increased postoperative pain control. The present study is coming close to this study and supports intraperitoneal route of local anaesthetic is effective in controlling postoperative laparoscopy surgery pain.

Study of Steen Moinche et $\mathrm{al}^{8}$ showed intraperitoneal and mesoperitoneal and mesosalpinx local block have impact on postoperative pain after laparoscopic surgery. He said up to $150 \mathrm{mg}$ can be used safely intraperitoneally. It is useful for postoperative pain of laparoscopic surgery.

A study by Gharabeh $\mathrm{KI}$ and $\mathrm{Al}$ Jaberi TM, ${ }^{9}$ they studied shoulder pain after laparoscopic cholecystectomy and delayed return to normal activities. Study in 75 patients, 37 bupivacaine $10 \mathrm{~mL}$ of $25 \%$ instilled into gall bladder bed and Calot's triangle area at the end of cholecystectomy - only $16 \%$ had shoulder pain compared control $60.5 \%$. The difference is significant ( $\mathrm{P}$ 0.0002). So local bupivacaine is effective in reducing such pain, present study coincides with the same.

Study of Weber A, Munoz J, Garteiz D, Cueto J,10 on subdiaphragmatic bupivacaine instillation to control 
postoperative pain at laparoscopic surgery. The results showed a considerable reduction of postoperative pain during first 48 hours after surgery in patient receiving bupivacaine instillation. This study concludes that instillation a long acting anaesthetic such as bupivacaine in subdiaphragmatic space after laparoscopic procedure is effective in reduction of postoperative pain. Present study is similar to author's study supporting intraperitoneal instillation of bupivacaine.

A study of Cunniffe MG, McAnena OJ, Dar MA, Calleary J and Flynn $\mathrm{N}, 11$ on a prospective randomized trial of intraoperative bupivacaine irrigation for management of shoulder-tip pain following laparoscopy. Postoperative Shoulder-Tip Pain (STP) frequently occurs following laparoscopic surgery. In an attempt to abrogate this complication, we prospectively evaluated the efficacy of intraoperative irrigation of the diaphragm with bupivacaine. Intraperitoneal irrigation with bupivacaine to both hemidiaphragms at the end of surgery significantly reduces both frequency and intensity of STP following laparoscopic procedures thus reducing patient morbidity.

A study of Buck L, Verras MN, Miskry T, Ruston J and Magos $A, 12$ on intraperitoneal bupivacaine for the reduction of postoperative pain following operative laparoscopy. This pilot case-control study was carried out to determine the value of intraperitoneal irrigation with a long-acting local anaesthetic agent in reducing postoperative analgesic requirements following gynaecological operative laparoscopy. Twenty women undergoing gynaecological laparoscopic surgery were recruited to receive dilute bupivacaine instilled into the peritoneal cavity at the completion of surgery. Analgesic requirements were assessed during the first 10 hours, and pain scores at 4 and 24 hours. Analgesic requirements were then compared with historical controls. Our results revealed that the total parenteral opioid requirement after bupivacaine was significantly less than in the control group.

A study of Ahmed BH, Ahmed A, Tan D, Awad ZT, Al-Aali AY, Kilkenny J 3rd, Orlando FA, Al-Chalabi A, Crass R and Alrawi SJ.13 On post-laparoscopic cholecystectomy, pain effects of intraperitoneal local anaesthetics on pain control - a randomized prospective double-blinded placebo-controlled trial. Intraperitoneal irrigation of the diaphragmatic surface and gallbladder fossa using normal saline, bupivacaine or lignocaine may effectively control visceral abdominal pain after an LC. Two hundred patients with similar demographics undergoing elective LC were randomized to one of four groups of 50 patients each including Group A placebo control, Group B with isotonic saline irrigation, Group C with bupivacaine irrigation and Group D with lignocaine irrigation. All patients received pre-peritoneal abdominal wall infiltration with 0.25 percent bupivacaine to control parietal (somatic) abdominal pain. The visual analogue and verbal rating pain scores at $0,4,8,12$ and 24 hours for both shoulder and abdominal pain were recorded in a prospective double-blind fashion at four points during the first 24 postoperative hours. Analgesia requirements, vital signs, blood glucose and incidence of nausea and vomiting were also recorded.

A study of Pasqualucci A, Contardo R, Da Broi U, Colo F, Terrosu G, Donini A, Sorrentino M, Pasetto A, Bresadola F,14 on the effects of intraperitoneal local anaesthetic on analgesic requirements and endocrine response after laparoscopic cholecystectomy: a randomized double-blind controlled study. This randomized double-blind placebo-controlled study was designed to evaluate the effects on postoperative pain of the local anaesthetic, $0.5 \%$ bupivacaine with epinephrine, sprayed hepatodiaphragmatically under the surgeon's direct view during laparoscopic cholecystectomy. Metabolic endocrine responses to surgery (glucose and cortisol) and non-steroidal anti-inflammatory drug requirements were investigated as well as the presence of nausea, vomiting and sweating. Local anaesthetics in one group and placebo solutions in control were given. The degree of postoperative pain was assessed using the Visual Analogue Scale (VAS) and the Verbal Rating Scale (VRS) on arrival in the recovery room and subsequently at time intervals of $4 \mathrm{~h}, 8 \mathrm{~h}, 12 \mathrm{~h}$ and $24 \mathrm{~h}$. The results of this study indicate a significant decrease of postoperative pain in patients treated with local anaesthetic. VAS and VRS pain scores as well as respiratory rate and analgesic requirements were significantly lower in bupivacaine group.

Most studies also demonstrated that the effect of intraperitoneal bupivacaine is lasting postoperatively up to 6 hrs. Thus was observation of present study. This is explainable by pharmacokinetics of the drug as study of Ozer et al, also highlight the same.

Intraperitoneal route is simple, non-invasive, effective and economical, not associated with any complications as seen in present study. At the end of laparoscopic procedure instillation of $0.5 \%$ bupivacaine intraperitoneally vitals like pulse rate, mean arterial blood pressure are stable and complications like nausea, vomiting, analgesia requirement and hospital stay is significantly less compared to saline group. It is advisable for all patients undergoing laparoscopic surgeries intraperitoneally to reduce early postoperative pain and other side effects.

\section{CONCLUSION}

Each group was observed for the postoperative pain and complications like nausea, vomiting, shoulder tip pain, analgesic requirement, hospital stay from 0 hour to $8^{\text {th }}$ hour by VAS scale for pain.

Postoperative pain was significantly less in Group B (Bupivacaine $0.5 \%$ ) from 0 to $6^{\text {th }}$ hour. It is non-invasive, simple and effective and economical to the patients. It is not associated with any complications, side effects as seen in this study.

$0.5 \%$ Bupivacaine intraperitoneal instillation is advisable to all eligible patients undergoing laparoscopic surgery. It is more effective for abdominal surgeries like hysterectomy, appendicectomy and cholecystectomy.

\section{REFERENCES}

1. Wylie WD, Churchill-Davidson. A practice of anesthesia. In: Healy TEJ, Knight PR, eds. $7^{\text {th }}$ ed. London: Arnold Press 2003:893.

2. Miller RD. Miller's anesthesia. In: Anesthesia for laparoscopic surgery. $6^{\text {th }}$ ed. US: EL Sevier Churchill Livingstone 2005:2285.

3. Goldstein A, Grimault P, Henique A, et al. Preventing postoperative pain by local anaesthetic instillation after laparoscopic gynaecologic surgery: a placebo controlled 
comparison of bupivacaine, ropivacaine. Anesth Analog 2000;91(2):403-7.

4. Chundrigar T, Hedges AR, Morris R, et al. Intraperitoneal bupivacaine for effective pain relief after laparoscopic cholecystectomy. Ann R Coll Surg Engl 1993;75(6):437-9.

5. Narchi P, Benhamou D, Fernandez H. Intraperitoneal local anaesthetic for shoulder pain after day case laparoscopy. Lancet 1991;338(8782-8783):1569-70.

6. Maharjan SK, Shrestha S. Intraperitoneal periportal instillation of bupivacaine for pain after laparoscopic cholecystectomy. Kathmandu Univ Med J 2009;7(25): 50-3.

7. Berven S, Hovarth K, Brooks DC. The effect of topical intraperitoneal bupivacaine on post-operative pain following laparoscopic cholecystectomy. Minimally Invasive Therapy and Allied Tech 1995;4(2):67-71.

8. Moinche $\mathrm{S}$, Jorgensen $\mathrm{H}$, Wettersleve J, et al. Local anaesthesia instillation for post-operative pain relief after laparoscopy: a qualitative, quantitative systemic review of intraperitoneal port site infiltration and mesosalpinx block. Anesth Analg 2000;90(4):899-912.

9. Gharaiben KI, Al-Jaberi TM. Bupivacaine instillation into gall bladder bed after laparoscopic cholecystectomy does it decrease shoulder pain? J Laparoendosc Adv Surg Tech A 2000;10(3):137-41.
10. Weber A, Munoz J, Garteiz D, et al. The use of subdiaphragmatic bupivacaine instillation to control postoperative pain after laparoscopic surgery. Surg Laparosc Endosc 1997;7(1):6-8.

11. Cunniffe MG, McAnena OJ, Dar MA, et al. Prospective randomized trial of intraoperative bupivacaine irrigation for management of shoulder tip pain following laparoscopy. Am J Surg 1998;176(3):258-61.

12. Buck L, Verras MN, Miskry $\mathrm{T}$, et al. Intraperitoneal bupivacaine for the reduction of post-operative pain following operative laparoscopy: a pilot study and review of the literature. J Obstet Gynaecol 2004;24(4):448-51.

13. Ahmed BH, Ahmed A, Tan D, et al. Post laparoscopic cholecystectomy pain effects of intraperitoneal local anaesthetic in pain control a randomized prospective double blind placebo control trial. Am Surg 2008;74(3):201-09.

14. Pasqualucci A, de Angelis A, Contardo R, et al. Pre-emptive analgesia: intraperitoneal local anaesthetic in laparoscopic cholecystectomy. A randomized double blind placebo controlled study. Anaesthesiology 1996;85(1): 11-20. 